\title{
Integration of Structural Components of Russian and Chinese Accounting Systems
}

\author{
Iurieva Larisa V. \\ Department of Accounting, Analysis and Audit \\ Ural Federal University, UrFU \\ Ekaterinburg, Russia \\ l.v.iuryeva@urfu.ru
}

\author{
Sinianskaia Elena R. \\ Department of Accounting, Analysis and Audit \\ Ural Federal University, UrFU \\ Ekaterinburg, Russia \\ e.r.sinyanskaya@urfu.ru
}

\author{
Savostina Olga V. \\ Department of Accounting, Analysis and Audit \\ Ural Federal University, UrFU \\ Ekaterinburg, Russia \\ o.v.savostina@urfu.ru
}

\begin{abstract}
The article compares the theoretical and methodological foundations of accounting in the Russian Federation and the People's Republic of China in the context of a single concept of their integration into the system of the international financial reporting standards and increasing its informativity for the further financial and economic analysis. The emergence of Russian and Chinese companies on the world market makes them meet the already established unified requirements for the provision of financial reporting, which increases the responsibility of the managers performing accounting and analytical functions for the reliability of the provided information. The work considers the views of leading Russian and Chinese scientists on the role and place of various types of accounting aspects, used in the management and planning of the economic activities, including theoretical provisions and the experience of their practical application from Russian and international citation bases SKOPUS and RSCI. The comparison was made by the main structural components: financial accounting regulated by the national Ministries of Finance and management accounting formed by the companies' management. The article identifies common features and small differences, proving the possibility of Russian organizations to adopt the best practices in the implementation of various methods and ways of accounting policy formation. The authors also consider the most interesting and promising methods of cost accounting and costing used by the Chinese companies, which make it possible to significantly enhance the effectiveness of strategic planning and control in the accounting and analytical sphere.
\end{abstract}

Keywords - Management accounting; financial accounting; accounting system

\section{INTRODUCTION}

The methodology of accounting and reporting, which is the main source of the economic information, is gaining increasing scientific and practical interest from the standpoint of rising the possibility of their unification in the context of unified requirements set by International Financial Reporting Standards (hereinafter - IFRS). In the modern world, information has become a resource. It is the accounting system (financial and management accounting) that makes it possible to form this resource in relation to the financial, business, production and all other aspects of the organization's activities. At the same time, it fully contributes to the realization of the economic and social interests of the enterprise, on the one hand, and state and municipal bodies, credit organizations and other users of financial statements, on the other hand.

Approaches and positions of the European scientists and practitioners, who are often also the developers of the regulations and standards, are very extensive. They are built on the significant experience of the countries associated with the world and European integration for a long period. However, Russia and China, as countries with similar economic and political regimes and modern development trends, are, in the authors' view, the most interesting object of the research. They carry out the processes of reforming the planned and closed economy into a market economy, allowing individual enterprises to carry out independent foreign economic activities, which requires compliance with the international reporting requirements, primarily the reliability and publicity of the accounting.

The greatest interest in the accounting system is the management accounting, which, unlike the financial one, is the least subject to the state regulation, but at the same time, it should be implemented in the context of a unified concept of the formation and in the use of the financial results of an enterprise or organization. The variability of management accounting methods allows using more flexible approaches taking into account the industry specifics and regional peculiarities, which contributes to the improvement of 
accounting processes by analyzing the experience of the successful firms.

Undoubtedly, the possibility of using the accounting experience of the PRC, which has made a huge leap in economic development over the past decades, is important for the Russian science and the practical activities of the Russian organizations in the accounting and analytical sphere for the effective implementation of cooperation and interaction.

Management accounting in China has much in common with the Western model and in some ways catches up with it. China uses tools and methods - either by adopting technology from the West, or by developing a domestic methodology, or applying a combination of two models - to meet the needs of enterprises in evaluating the performance by fact and for organizational planning and management [1].

A lot of works of the foreign and domestic scientists have been devoted to the research of the management accounting organization and ensuring the effectiveness of the innovation activity: Liu Tsin, C.T. Horngren, Drury K., Belkaoui A., Mulendorf R. Karenbauer M., Atkinson A., Kaplan R., Karpova T.P., Shreder N.G., Vakhrushina M.A., et al.

The management accounting plays a pivotal role during turning points in the history of the enterprise development as well as in cases of unforeseen incidents and natural disasters [2].

Datszun U., $\mathrm{Nu}$ Yansiu believe that the management accounting methods are very flexible; the financial accounting methods have a more stable and patterned nature [3].

K. Drury believes that management accounting means preparing the information necessary to carry out the managerial activities, such as decision making, planning, control and regulation [4].

A. Atkinson and the group of authors formulate management accounting as a value adding process for the continuous improvement of the planning, designing, measuring and functioning of the financial and non-financial information systems that directs management actions, motivates behavior, supports and creates the cultural values necessary to achieve strategic, tactical and operational objectives of the organization [5].

A. Belkaoui believes that the management accounting system is engaged in determining the cost of production at the centers of responsibility [6].

Thus, the main purpose of the management accounting is the production of information for the management of the organization to make the management decisions [5].

Practical experience in the use of the management accounting data is reflected in the works of: Reef Lawson, Garisson Ch., Shonberger R., bookkeeper Robert Anthony, Lavson V., Kerimov V.E., V.I. Tkach and M.V. Tkach, Paliy V.V., et al. The state of the management accounting in China was investigated by the Institute of Management Accountants (IMA), the USA.
The review of the scientific works allowed one to generalize the accumulated experience and, at the present time, to reveal the absence of a systematic approach to the development of a unified technology of the management accounting that makes it possible to use the experience of the PRC.

\section{RESEARCH METHODS}

The methodological basis of the study was the normative and legal acts in the field of the accounting, the works of the leading domestic and foreign economists carrying out researches in the field of the accounting, and the materials from the periodicals. The methodological basis of the research is the application of the general scientific methods of cognition, methods of the comparative research, monographic method, and special methods of accounting.

The multidimensional methods of analysis of dependencies, reduction of dimension and classification, methods of the time series analysis and forecasting, and simulation technology were used as a tool.

\section{RESULTS AND DISCUSSION}

The system of the accounting reform in Russia is aimed at maximizing the convergence of its principles and requirements with the current international standards, allowing further financial and economic analysis by common methods and comparable information sources. Traditionally, the accounting consists of two main elements - financial and managerial. The tax accounting is singled out as an independent direction, corresponding to the financial accounting data. For this purpose, the national standards, developed on the conceptual bases of the international ones, but taking into account the peculiarities of the Russian economy and taxation, have been created and kept on to be improved.

A distinctive feature of the accounting system of the PRC is a stronger relationship with the international standards of accounting and financial reporting. This is due to the strong dependence of the PRC on the world capital market, which necessitated the transformation of the accounting system in accordance with the international practice. The China Accounting Standards Committee (CASC) is the official body that ensures the implementation of the international financial reporting standards. It has adapted and recommended the "Basic Accounting Rule (standard)" - the national name of the IFRS Concept - and about forty current rules (standards).

The comparative characteristics of the principles used in the accounting system of Russia and China are presented in Tab. 1.

Thus, the basic concept of the normative regulation of accounting and its organizational principles in Russia and China largely coincide. It is focused on the fullest and most reliable reflection of all the facts of the economic life of the enterprises (fixation of the daily operations and making corresponding records, calculations and distributions on a regular basis) to provide the information to various groups of users, as well as to analyze financial statements. The difference is mainly in the methods used, as well as a more 
significant relationship of Russian accounting with the tax one.

TABLE I. The COMPARATIVE Characteristics OF THE PRINCIPLES OF THE TWO COUNTRIES

\begin{tabular}{|c|c|c|}
\hline $\begin{array}{c}\text { Line of } \\
\text { Compariso } \\
\text { n } \\
\end{array}$ & Russia & China \\
\hline Use of IFRS & $\begin{array}{l}\text { Lies in the basis of } \\
\text { national standards }\end{array}$ & Used as national standards \\
\hline $\begin{array}{l}\text { The used } \\
\text { model of } \\
\text { accounting }\end{array}$ & $\begin{array}{l}\text { The principles of the } \\
\text { continental model }\end{array}$ & Continental \\
\hline $\begin{array}{l}\text { Regulatory } \\
\text { authority }\end{array}$ & RF Ministry of Finance & PRC Ministry of Finance \\
\hline $\begin{array}{l}\text { Users of } \\
\text { information }\end{array}$ & $\begin{array}{l}\text { Any interested users, in } \\
\text { accordance with the } \\
\text { information needs }\end{array}$ & First of all, investors \\
\hline $\begin{array}{l}\text { Elements of } \\
\text { the } \\
\text { accounting } \\
\text { system }\end{array}$ & $\begin{array}{l}\text { 1) the object of } \\
\text { accounting; } \\
\text { 2) the subject of } \\
\text { accounting; } \\
\text { 3) accounting methods; } \\
\text { 4) users of accounting } \\
\text { information; } \\
\text { 5) normative regulation; } \\
\text { 6) internal control }\end{array}$ & $\begin{array}{l}\text { 1) a set of national } \\
\text { accounting standards; } \\
\text { 2) a list (plan) of } \\
\text { accounts; } \\
\text { 3) the technique of } \\
\text { accounting work; } \\
\text { 4) the technology of } \\
\text { accounting } \\
\text { summarizing; } \\
\text { 5) documented resulting } \\
\text { data (financial statements) }\end{array}$ \\
\hline $\begin{array}{l}\text { Objects of } \\
\text { accounting }\end{array}$ & $\begin{array}{l}\text { 1) facts of economic life; } \\
\text { 2) assets; } \\
\text { 3) obligations; sources of } \\
\text { activities financing; } \\
\text { 4) income; } \\
\text { 5) expenses; } \\
\text { 6) other objects }\end{array}$ & $\begin{array}{l}\text { 1) money resources; } \\
\text { 2) financial investments; } \\
\text { 3) the movement of } \\
\text { values; } \\
\text { 4) debt obligations and } \\
\text { payments; } \\
\text { 5) change of the capital; } \\
\text { 6) incurred costs; } \\
\text { 7) income and expenses } \\
\text { comparison }\end{array}$ \\
\hline $\begin{array}{l}\text { Professional } \\
\text { judgment of } \\
\text { the subjects }\end{array}$ & $\begin{array}{l}\text { Proclaimed, but is not } \\
\text { actually used }\end{array}$ & $\begin{array}{l}\text { Proclaimed and is actively } \\
\text { used }\end{array}$ \\
\hline $\begin{array}{l}\text { System of } \\
\text { legislative } \\
\text { regulation }\end{array}$ & $\begin{array}{l}\text { Four-level: } \\
\text { 1) Federal legislation; } \\
\text { 2) national accounting } \\
\text { standards (PBU) and card } \\
\text { of accounts; } \\
\text { 3) methodological } \\
\text { recommendations and } \\
\text { instructions for applying } \\
\text { the standards of the first } \\
\text { two levels; } \\
\text { 4) regulatory } \\
\text { documentation and the } \\
\text { accounting policies of the } \\
\text { organization }\end{array}$ & $\begin{array}{l}\text { Two-level: } \\
\text { 1) the basic normative \& } \\
\text { legal documents relating } \\
\text { to the accounting system } \\
\text { of the PRC as a whole and } \\
\text { containing provisions of a } \\
\text { methodological nature; } \\
\text { 2) regulatory accounting } \\
\text { documents of an applied } \\
\text { (special) nature, including } \\
\text { the specific guidance on } \\
\text { accounting and reporting }\end{array}$ \\
\hline $\begin{array}{l}\text { Basic } \\
\text { normative } \\
\text { documents }\end{array}$ & $\begin{array}{l}\text { Federal Law "On } \\
\text { Accounting", the RF Tax } \\
\text { Code, the Federal Law } \\
\text { "On Auditing", the } \\
\text { Accounting Regulations } \\
\text { (national standards), the } \\
\text { RF Labor Code, regulatory } \\
\text { acts of the Ministry of } \\
\text { Finance and the Central } \\
\text { Bank of Russia }\end{array}$ & $\begin{array}{l}\text { The State Law "On } \\
\text { Accounting", the law "On } \\
\text { the Certification of the } \\
\text { Professional } \\
\text { Accountants", the State } \\
\text { Law "On Auditing in the } \\
\text { People's Republic of } \\
\text { China", the State Law "On } \\
\text { Managing the Collection } \\
\text { of Taxes", the Law } \\
\text { "Accounting Standards" }\end{array}$ \\
\hline $\begin{array}{l}\text { Consti } \\
\text { of a c }\end{array}$ & $\begin{array}{l}\text { The standard card of } \\
\text { accounts has a two-digit }\end{array}$ & $\begin{array}{l}\text { The number of each of } \\
\text { the six classes of accounts }\end{array}$ \\
\hline
\end{tabular}

\begin{tabular}{|c|c|c|}
\hline $\begin{array}{c}\text { Line of } \\
\text { Compariso } \\
\mathbf{n} \\
\end{array}$ & Russia & China \\
\hline $\begin{array}{l}\text { accounts as } \\
\text { a universal } \\
\text { way of } \\
\text { encoding } \\
\text { economic } \\
\text { information } \\
\text { in } \\
\text { accounting } \\
\text { data }\end{array}$ & $\begin{array}{l}\text { numbering; the accounts } \\
\text { are grouped according to } \\
\text { economically similar } \\
\text { characteristics into } \\
\text { sections consisting of ten } \\
\text { accounts. If it is necessary } \\
\text { to conduct analytical } \\
\text { accounting, an enterprise } \\
\text { independently introduces a } \\
\text { system of sub-accounts. }\end{array}$ & $\begin{array}{l}\text { is the first digit in the } \\
\text { consecutive number of the } \\
\text { accounts included in its } \\
\text { structure. Each class } \\
\text { contains accounts with } \\
\text { four-digit numbers. In } \\
\text { addition, each account has } \\
\text { a corresponding account } \\
\text { serial number. } \\
\text { The National Card of } \\
\text { Accounts of the People's } \\
\text { Republic of China is } \\
\text { mandatory, but provides } \\
\text { for the possibility of } \\
\text { enterprise to use its own } \\
\text { accounts, if it is properly } \\
\text { justified for tax and other } \\
\text { control government } \\
\text { agencies. }\end{array}$ \\
\hline $\begin{array}{l}\text { Measuring } \\
\text { system }\end{array}$ & $\begin{array}{l}\text { Natural labor, money. All } \\
\text { transactions denominated } \\
\text { in the foreign currencies } \\
\text { are subject to recalculation } \\
\text { into rubles at the exchange } \\
\text { rate of the Central Bank of } \\
\text { the Russian Federation as } \\
\text { of the date of the } \\
\text { transaction and by the } \\
\text { reporting date }\end{array}$ & $\begin{array}{l}\text { Natural, labor, money. } \\
\text { The monetary currency of } \\
\text { all operations of the } \\
\text { enterprise is the national } \\
\text { currency. But, unlike } \\
\text { Russia, the documents can } \\
\text { be drawn up in a currency } \\
\text { other than the national } \\
\text { one, if this follows from } \\
\text { the specifics of the } \\
\text { transaction being } \\
\text { conducted. At the end of } \\
\text { the year, before the } \\
\text { formation of the report, } \\
\text { recalculation in yuan } \\
\text { should be made according } \\
\text { to special rules. }\end{array}$ \\
\hline $\begin{array}{l}\text { Language } \\
\text { for } \\
\text { documentati } \\
\text { on } \\
\text { maintaining } \\
\text { and } \\
\text { reporting }\end{array}$ & Russian & $\begin{array}{l}\text { The working language of } \\
\text { China's accounting system } \\
\text { is the official language. If } \\
\text { there is a need, it is } \\
\text { allowed to execute } \\
\text { financial and economic } \\
\text { operations with } \\
\text { documents in some } \\
\text { minority dialect of the } \\
\text { Chinese population or in a } \\
\text { foreign language. }\end{array}$ \\
\hline $\begin{array}{l}\text { Accounting } \\
\text { structure }\end{array}$ & $\begin{array}{l}\text { The structure of } \\
\text { accounting should } \\
\text { correspond to the type of } \\
\text { activity and scope of the } \\
\text { organization. } \\
\text { management is carried out } \\
\text { by the chief accountant, } \\
\text { who is responsible for the } \\
\text { organization of the internal } \\
\text { control system. It is } \\
\text { allowed to use the services } \\
\text { of specialized audit firms } \\
\text { instead of accounting. }\end{array}$ & $\begin{array}{l}\text { Each organization builds } \\
\text { an accounting structure } \\
\text { based on the functional } \\
\text { needs of the accounting } \\
\text { department. The chief } \\
\text { accountant is called } \\
\text { fuzsezhen (a responsible } \\
\text { person). }\end{array}$ \\
\hline $\begin{array}{l}\text { Structural } \\
\text { Elements of } \\
\text { Accounting }\end{array}$ & $\begin{array}{l}\text { It is subdivided into } \\
\text { financial, management, } \\
\text { and tax }\end{array}$ & $\begin{array}{l}\text { It is subdivided into } \\
\text { financial and management } \\
\text { (Chinese scientists do not } \\
\text { distinguish tax accounting } \\
\text { in a unified accounting } \\
\text { system) }\end{array}$ \\
\hline
\end{tabular}

Next, let us examine in more detail the interaction of these two structural components of accounting, both managerial and 
financial in the interpretation of Russian and Chinese researchers.

In a sense, both financial and management accounting serve the internal management in the enterprise, but their content is very different. Financial accounting, as a rule, reflects the result of already accomplished economic events and economic actions based on the continuity of accounting, its systematic character and comprehensiveness, focusing on the production and economic activities of the enterprises and allows us to determine the trends of the future development. The main content of the management accounting is to predict the future, to influence the adoption of managerial decisions and exercise control through the collecting and processing the information about the past, present and future. The content of the management accounting is more detailed in comparison with the financial accounting.

The financial accounting reflects the financial condition and results of the activities, schematically illustrates the changes in capital, costs, and profit indicators without providing the specific content and details in the abovementioned information.

The management accounting, according to the business objectives and plans for the future, is responsible for the overall planning and control in the enterprise, it provides information on sales volumes, capital changes, costs and profits and other aspects of the basic information. In accordance with the current sales volumes, capital status, product and profit indicators, it contains requirements for the information regarding the achievement of the plan, the development of a new product and the features of its production, the acquisition, construction and operation of the equipment, the supply and storage of the materials, the opening of sales channels, prices of the products sales, etc. The management accounting serves to meet the daily information needs of business executives at all levels to achieve the effectiveness of the internal planning and the need to monitor production and entrepreneurial activities.

In the works of Russian theorists, there are essentially related parameters of comparison, presented in Tab. 2 .

TABLE II. SOME PARAMETERS FOR THE COMPARISON OF THE CONTENT OF THE FINANCIAL AND MANAGEMENT ACCOUNTING

\begin{tabular}{|l|l|l|}
\hline \multicolumn{1}{|c|}{ Attribute } & Financial Accounting & \multicolumn{1}{|c|}{$\begin{array}{c}\text { Management } \\
\text { Accounting }\end{array}$} \\
\hline $\begin{array}{l}\text { The data in } \\
\text { the basis of } \\
\text { the } \\
\text { accounting }\end{array}$ & Actual, normative & $\begin{array}{l}\text { Actual, normative, } \\
\text { budgetary, forecasted }\end{array}$ \\
\hline $\begin{array}{l}\text { Forms of } \\
\text { reporting }\end{array}$ & $\begin{array}{l}\text { Balance sheet, statement } \\
\text { of financial results, } \\
\text { statement of cash flows, } \\
\text { etc. }\end{array}$ & $\begin{array}{l}\text { Internal reports. The } \\
\text { form is not regulated by } \\
\text { the normative documents }\end{array}$ \\
\hline $\begin{array}{l}\text { Frequency of } \\
\text { reporting }\end{array}$ & $\begin{array}{l}\text { Monthly, quarterly, } \\
\text { annually }\end{array}$ & $\begin{array}{l}\text { The reports can be } \\
\text { compiled daily, weekly, } \\
\text { monthly, on request }\end{array}$ \\
\hline
\end{tabular}

In the Russian theoretical thought regarding the subject of the management accounting there is still no single point of view. In the opinion of M.A. Vakhrushina [7], the management accounting is an independent direction of the organization's accounting records, which provides information support for its activities management system. Most researchers share this point of view.

The management accounting is considered in a narrow and broad sense. In a narrow sense, it is a micro-management accounting that is connected with the modern conditions of the market economy and aims to strengthen the internal management of the enterprise, to achieve high economic profit indicators. Besides, its purpose is to reflect the main objects of modern forms of entrepreneurial activity by processing and reprocessing financial and other information, to create opportunities for the economic forecasts compiling, management decisions making, planning, controlling, and responsibilities distribution. In a broad sense, the management accounting is used to generalize the features of the modern accounting system and its difference from the traditional accounting; it is directly engaged in forecasting, decisionmaking, planning, monitoring, and analysis of economic activities.

Among Russian scientists, Ya.V. Sokolov adheres to this position. In his works, the researcher classifies the understanding of the management accounting in a broad and narrow sense, explains in detail their modifications in the world practice of accounting [8]. The approach of Ya.V. Sokolov as a whole reflects the position of the majority of Russian theoreticians and defines the financial accounting as an orderly system for collecting, recording and summarizing information in monetary terms about the assets, liabilities of the organization and their movement by the continuous, uninterrupted, and documented accounting of all business transactions [9].

There are different views on the role of the management accounting in the industrial enterprises in terms of innovative economy. For example, Zhang Shuang notes that the management accounting in the narrow sense is a micromanagement accounting that is related to the current conditions of the market economy and aims to strengthen internal management of the enterprise [10].

In general, the Chinese researchers note that the financial management and management accounting are the main item of the activity of the accountant and accounting service. Liu Tsin explains that historically the management accounting has separated from the traditional accounting, after which the sphere of the latter's activity narrowed to the processing of only a part of the information about the enterprise financial activity, namely the content for the external reporting. This type of accounting became known as the financial accounting. [11].

In contrast, the management accounting for most Chinese researchers is defined as "internal accounting reporting", which is aimed at the improving the economic efficiency of the enterprises; and through a number of specialized methods of processing information provided by the financial reporting 
in accordance with day-to-day planning and control of economic activities it helps the decision-makers [12].

Financial accounting, according to Professor Ma Tao, is focused mainly on the level of business operations or information issues of the enterprise activity [13]. Let us consider the differences between the management and financial accounting, which are distinguished by the theorists from the PRC.

Subjects of the management accounting can be represented by several levels according to type of work:

1) persons responsible for different accounting objects;

2) persons engaged in summarizing the overall results of the economic activities for the given facilities;

3) persons involved in the analysis and the overall assessment of the state of the enterprise.

This provision is not clearly outlined in the classifications by Russian scientists, however, in the authors' opinion, it is important as it outlines the circle of employees directly engaged in the financial and management accounting, reducing the "mythical nature" of the latter to a minimum, as noted by Ya.V. Sokolov.

Using the financial accounting indicators, the management accounting (by means of mathematical and statistical analysis methods) provides all levels of management within the enterprise with the short-term and long-term business strategies, planning, managing and monitoring economic activities to increase its efficiency.

By choosing the form of the accounting currency, using a double entry, relying on the basic principles of accounting and the established procedure for its conduct, the financial accounting is reduced to an analysis of the industrial and entrepreneurial activities. The financial accounting reflects the indicators of the financial statements for a certain periods of time; the financial statements and accounting information for the external users (the relevant economic entities and their groups, including the shareholders and potential investors; financial and tax authorities; other authorities; banks, creditors, etc.) are formed.

The Russian researchers also highlight this position of differences. The users of the management accounting information include managers of different levels, as well as external contractors. The users of the financial accounting information in the world practice traditionally include: shareholders, investors, buyers, credit institutions, statistics bodies, etc.

L.A. Zharikova defines this comparative position as "the users of the accounting results" and notes that the results of the financial accounting are mainly focused on the needs of the companies' shareholders, the holders of the debentures and other securities, and the potential investors. Only the personnel of the firm uses the results of the management accounting, it is a kind of "kitchen" of the enterprise, where the materials for managers are being prepared [14].
The financial accounting, as noted by Sun Lin, "is focused mainly on the level of business operations or information issues of the enterprise". Through the ascertaining, processing, evaluation, accounting and financial reporting as the main instrument, financial accounting meets the interests of various groups of users inside and outside the enterprise, who need quantitative information about the financial position of the enterprise.

Through the ascertaining, processing, evaluation, accounting and financial reporting as the main instrument, the financial accounting meets the interests of various groups of users inside and outside the enterprise, who need the quantitative information about the financial position of the enterprise. The financial accounting information uses a monetary unit as the primary unit of measurement and scale construction and reflects the cash flow or the economic history of the enterprise [15].

Since the management accounting is of the greatest interest for the researchers in terms of acquiring the experience of the Chinese companies and adapting it to the activities of the Russian enterprises, especially in the field of innovations, let us dwell on the methods for implementing it.

The differences between the methods developed in the PRC and the RF often reflect the existing differences in the political and economic climate. At present, the Chinese companies are faced with the task of uniting the existing Chinese planning and control methods with the best Western methods, making them applicable to China's unique production environment and culture. Tab. 3 shows the development of Western and Chinese methods of calculation and management accounting.

TABLE III. PARALLEL DEVELOPMENT OF CALCULATION AND MANAGEMENT ACCOUNTING METHODS

\begin{tabular}{|l|l|}
\hline \multicolumn{1}{|c|}{ Western Method } & \multicolumn{1}{c|}{ Chinese Method } \\
\hline $\begin{array}{l}\text { Accounting by responsibility } \\
\text { centers }\end{array}$ & $\begin{array}{l}\text { System of cost control } \\
\text { responsibilities }\end{array}$ \\
\hline Cost / Profit Centers & Cost Control Center \\
\hline $\begin{array}{l}\text { Indicator tables / valuation } \\
\text { sheets }\end{array}$ & $\begin{array}{l}\text { Use of a combination of financial } \\
\text { and non-financial key indicators to } \\
\text { assess the effectiveness }\end{array}$ \\
\hline Market transfer prices & $\begin{array}{l}\text { Transfer prices based on the target } \\
\text { normative cost for the values chain }\end{array}$ \\
\hline «Beyond Budgeting» method & $\begin{array}{l}\text { Division of the budget for } \\
\text { planning and control; use of the } \\
\text { "comparative tables" }\end{array}$ \\
\hline Method of normative cost price & Basics of this approach \\
\hline
\end{tabular}

The methods of the management accounting in China continued to be developed from the beginning of the country's transition to the market economy. The companies were forced to move from the economic system in which the production costs and the selling price were fixed, where the most important performance indicator was the amount of the output, to the system in which the main purpose is to control the costs and maximize the profits. In order to survive in this changing environment, it was necessary to redesign the planning systems and methods, to find new methods for productivity evaluation, and to expand the role of accounting [16]. 
Table 4 presents the data on the use of the various management accounting methods at the enterprises of the PRC. The columns represent the numerical values characterizing the number of enterprises of a certain form of ownership (the first number). The second figure (in parentheses) means the percentage of the total number of the enterprises that gave a positive reply in the group. For instance, 84 state-owned enterprises use operational planning methods, which is $26 \%$ of the total number of enterprises surveyed.

The table uses the data from the study of the management accounting state in China conducted by the Institute of Management Accountants (IMA®). The study included a survey of 209 companies. The research team included Reef Lawson, Professor and Vice President of the IMA Research Department; Gilliang Young, a professor at the Hong Kong University of Science and Technology, retired; and Pinzhang Ding, IMA's chief adviser on China, a former member of the PRC Ministry of Finance and the Chinese Institute of Certified Public Accountants (CICPA).

TABLE IV. The use of the Management Accounting Methods By THE CHINESE ENTERPRISES

\begin{tabular}{|c|c|c|c|}
\hline & $\begin{array}{c}\text { State- } \\
\text { owned } \\
\text { enterprises }\end{array}$ & $\begin{array}{c}\text { Registered } \\
\text { enterprises } \\
\text { in federal or } \\
\text { municipal } \\
\text { ownership }\end{array}$ & $\begin{array}{c}\text { Unregistered } \\
\text { enterprises } \\
\text { in private } \\
\text { ownership }\end{array}$ \\
\hline $\begin{array}{l}\text { Methods of } \\
\text { operational planning }\end{array}$ & $84(26)$ & $91(10)$ & 89 (59) \\
\hline $\begin{array}{l}\text { Flexible financial } \\
\text { planning }\end{array}$ & $25(5)$ & $43(3)$ & $29(8)$ \\
\hline $\begin{array}{l}\text { Planning of capital } \\
\text { investments }\end{array}$ & $50(10)$ & $50(3)$ & $48(14)$ \\
\hline $\begin{array}{l}\text { Analysis of fixed / } \\
\text { variable costs }\end{array}$ & $43(9)$ & $43(3)$ & 77 (33) \\
\hline $\begin{array}{l}\text { Costing based on } \\
\text { costs chain }\end{array}$ & $6(1)$ & $43(3)$ & $34(11)$ \\
\hline $\begin{array}{l}\text { Method of normative } \\
\text { cost price }\end{array}$ & $28(5)$ & $40(2)$ & $55(21)$ \\
\hline $\begin{array}{ll}\text { Accounting by } \\
\text { Responsibility } \\
\text { Centers }\end{array}$ & $68(15)$ & $89(8)$ & $81(34)$ \\
\hline Material incentive & $72(18)$ & $80(4)$ & $84(38)$ \\
\hline Efficiency mark & $67(18)$ & $40(2)$ & $78(32)$ \\
\hline Standard Costing & $11(2)$ & $20(1)$ & $36(9)$ \\
\hline $\begin{array}{ll}\text { Internal } & \text { Transfer } \\
\text { Pricing } & \end{array}$ & $35(6)$ & $80(4)$ & $67(20)$ \\
\hline $\begin{array}{l}\text { Traditional } \\
\text { distribution } \\
\text { overhead costs }\end{array}$ & $42(8)$ & $60(3)$ & $64(21)$ \\
\hline $\begin{array}{l}\text { Cost Accounting by } \\
\text { Responsibility Centers }\end{array}$ & $6(1)$ & $0(0)$ & $12(3)$ \\
\hline Life cycle costing & $17(3)$ & $40(2)$ & $14(3)$ \\
\hline "Benchmarking" & $11(2)$ & $20(1)$ & $9(2)$ \\
\hline $\begin{array}{l}\text { Theory of } \\
\text { constraints }\end{array}$ & $12(2)$ & $0(0)$ & $19(4)$ \\
\hline Added value & $6(1)$ & $0(0)$ & $18(4)$ \\
\hline
\end{tabular}

As follows from the table, there were no significant differences in the use of the methods for the companies of various forms of ownership. This proves that the state-owned companies use the same methods of the management accounting as the private firms, and that the reasons of their lower financial performance are due to the other factors, for instance, due to the other organizational purposes. Statistical analysis of the common features in the use of the management accounting techniques made it possible to distinguish three main factors.

The first factor focuses on the use of the method of "benchmarking", the theory of constraints, the method of costs accounting by the responsibility centers, life cycle costing, and costing based on a cost chain, but not on a flexible budgeting. This factor can be interpreted as an understanding of the costs composition, usually, in the long run, an assessment of the firm's competitive ability.

The second factor is related to the analysis of the constant/variable costs, the normative cost method, and the internal transfer pricing and is interpreted as an understanding of cost behavior in order to increase the operational efficiency.

The third factor mainly sticks to the methods of material encouragement, evaluation of the effectiveness and accountability by the responsibility centers. The third factor deals with the traditional evaluation of the efficiency and the control function of accounting.

In the 1950s, the Chinese firms created a system of intracompany economic responsibility, setting the production targets for the different levels of the enterprise. This system used a whole range of the production indicators, including indicators of production, efficiency, quality, cost and safety, as well as many others, not limiting only to the indicators of cost and profitability. With a planned economy, this was necessary so that each enterprise considered itself as a part of a huge "conglomerate", in which the output of some manufacture is the production resource for the other. As a result, great attention was paid to maximizing the manufacture of the product for the smooth operation of the economy of the whole country.

Tab. 5 presents the data on the use of the various management accounting methods at the Russian enterprises, based on the study conducted by the authors. Columns 2 and 4 contain the numerical values characterizing the number of enterprises of a particular form of ownership participating in the study. Columns 3 and 5 indicate the percentage of the surveyed number of enterprises that responded positively in the group. The study included a survey of 150 companies.

TABLE V. The use of Management Accounting Methods by RUSSIAN ENTERPRISES

\begin{tabular}{|l|c|c|c|c|}
\hline & \multicolumn{2}{|c|}{$\begin{array}{c}\text { State and federal } \\
\text { enterprises }\end{array}$} & \multicolumn{2}{c|}{$\begin{array}{c}\text { Enterprises in } \\
\text { private ownership }\end{array}$} \\
\cline { 2 - 5 } & amount & percentage & amount & percentage \\
\hline $\begin{array}{l}\text { Total amount of } \\
\text { enterprises }\end{array}$ & 70 & 100 & 80 & 100 \\
\hline $\begin{array}{l}\text { Methods of } \\
\text { operational } \\
\text { planning }\end{array}$ & 60 & 86 & 69 & 86 \\
\hline $\begin{array}{l}\text { Flexible financial } \\
\text { planning }\end{array}$ & 5 & 7 & 25 & 31 \\
\hline Planning of capital & 50 & 71 & 34 & 43 \\
\hline
\end{tabular}




\begin{tabular}{|c|c|c|c|c|}
\hline & \multicolumn{2}{|c|}{$\begin{array}{c}\text { State and federal } \\
\text { enterprises }\end{array}$} & \multicolumn{2}{|c|}{$\begin{array}{c}\text { Enterprises in } \\
\text { private ownership }\end{array}$} \\
\hline & amount & percentage & amount & percentage \\
\hline \multicolumn{5}{|l|}{ investments } \\
\hline $\begin{array}{l}\text { Analysis of fixed / } \\
\text { variable costs }\end{array}$ & 40 & 57 & 60 & 75 \\
\hline $\begin{array}{l}\text { Costing based on } \\
\text { costs chain }\end{array}$ & 2 & 3 & 15 & 19 \\
\hline $\begin{array}{lr}\begin{array}{l}\text { Method } \\
\text { normative } \\
\text { price }\end{array} & \text { of } \\
\text { cost }\end{array}$ & 65 & 93 & 24 & 30 \\
\hline $\begin{array}{l}\text { Accounting by } \\
\text { Responsibility } \\
\text { Centers }\end{array}$ & 50 & 71 & 49 & 61 \\
\hline Material incentive & 30 & 43 & 60 & 75 \\
\hline Efficiency mark & 45 & 64 & 68 & 85 \\
\hline Standard Costing & 47 & 67 & 25 & 31 \\
\hline $\begin{array}{ll}\text { Internal } & \text { Transfer } \\
\text { Pricing } & \\
\end{array}$ & 7 & 10 & 10 & 13 \\
\hline $\begin{array}{l}\text { Traditional } \\
\text { distribution } \\
\text { overhead costs }\end{array}$ & 34 & 49 & 38 & 48 \\
\hline $\begin{array}{l}\text { Cost Accounting } \\
\text { by Responsibility } \\
\text { Centers }\end{array}$ & 50 & 71 & 28 & 35 \\
\hline Life cycle costing & 47 & 67 & 37 & 46 \\
\hline "Benchmarking" & 10 & 14 & 54 & 68 \\
\hline $\begin{array}{l}\text { Theory of } \\
\text { constraints }\end{array}$ & 8 & 11 & 20 & 25 \\
\hline Added value & 6 & 9 & 15 & 19 \\
\hline
\end{tabular}

As follows from Tab. 5, some discrepancies in the use of the methods by the public and private companies were found; this is due to the peculiarities of the Russian legislation. Statistical analysis of the common features in the use of management accounting techniques has made it possible to distinguish three main methods traditionally used at Russian enterprises. These are the methods of operational planning, normative cost and cost accounting by the responsibility centers.

It should be noted that this rather long-standing practice is complemented by the use of the Western method, using a balanced scorecard to obtain a harmonious idea of the collective productivity. While most of the companies included in our study do not openly associate the appraisal sheets with the organizational strategy, as one does with the Western method of using the balanced scorecard; in most cases, it is possible to safely assert that such hidden link exists at both Russian and Chinese enterprises.

\section{CONCLUSION}

Thus, at present, the national accounting systems of Russia and China are being reformed in accordance with the vector adopted in the European community. This is a focus on the maximum observance of the interests of the users of the reporting, primarily investors; the objective reflection of the information on the financial situation and the performance of the enterprise; ensuring the control of the assets from the perspective of possible benefits, caution in recognizing income and expenses.
In the normative and theoretical positions between China and Russia, there is much in common, which is expressed in the same principles of implementation and state regulation of the financial accounting as one of the components of accounting. The other component, called a management accounting, affects the organizational and practical issues of collecting, summarizing and analyzing the information on the methods and structure of the financial results formation, which in most cases depends on the enterprises and organizations management. The Chinese companies have acquired vast experience in this field, which is considered one of the priorities for business in the West, and that was one of the reasons for their successful development in the world market.

Choosing the method of the management accounting, which contributes to the most effective organization of the accounting and analytical process, the Russian enterprises can benefit from the experience of their Chinese colleagues not only in traditional activities, but also in the creation of the innovative manufactures. This is due both to similar historical conditions for the economies functioning of the two countries, and to the current potential of the top managers, who solve a complex of the financial, economic, technological and social tasks.

\section{References}

[1] A.O. Chemarina, T.B. Turischeva, "Evolution of Management Accounting in China," The Genesis of Genius, vol. 1-1, 2014, pp. 160166.

[2] U. Shilan, Tszou Guichan, Lin Tszianzhi, "Five Main Objectives of Agricultural Development in China," Journal of Natural Resources, vol. 16 (4), 2001, pp. 320-324.

[3] U. Datszun, Nu Yansiu, "Management Accounting," Dalian, 2007, pp.28-30.

[4] K. Drury, Management and Production Accounting. Introductory course, Moscow, 2016, 735 pp.

[5] A. Atkinson, R. Kaplan, Management Accounting, 3rd reprint. Ed. Atkinson E.A. Moscow: Williams, 2005, 874 p.

[6] A. Belkaoui, Conceptual Foundations of Management Accounting. Addison Wesley, 1980.

[7] M.A. Vakhrushina, Management Accounting, 9th reprint. Moscow, 2011, 569 pp.

[8] Ya.V. Sokolov, History of Accounting: textbook. Moscow, 2006, 288 pp.

[9] Ya.V. Sokolov, Managerial Accounting: textbook. Moscow, 2010, 250 pp.

[10] Chzhan Shuan, "Comparative Characteristics of the Development of Chinese and Russian Accounting Standards," Naukovedenie, vol. 2, 2015, pp. 62-66.

[11] Liu Tsin, "Comparative Analysis and Trends in the Development of the Management and Financial Accounting," East enterprises culture, pp. 258-262, April 2010.

[12] Van Unsin, He Susian, Yao Guansian, "Management Accounting," Beijing, 2011, pp. 20-23.

[13] Ma Tao, "Financial Accounting and Management Accounting: A Comparative Study," Finances and accounting in the Transport Sector, Issue 7 (vol. 192), 2003, pp. 35-38.

[14] L.A. Zharikova, Accounting in the Foreign Countries: textbook. Moscow, 2014, $211 \mathrm{p}$.

[15] Sun Lin, "The Development of the Accounting Regulation in the Countries with Economies in Transition and the Study of the Economic Consequences of the Internationalization of the Accounting Regulations 
by the Example of China," Proceedings of the St. Petersburg University of Economics and Finance. vol. 3 (75), 2012, pp. 7-14.
[16] L.V. Iurieva, E.V. Dolzhenkova, M.A. Kazakova, "Costs management accounting at industrial enterprises in conditions of the innovation economics". Moscow, 2015, 290 p. 